\title{
Tick-borne pathogens in Finland: comparison of Ixodes ricinus and $I$. persulcatus in sympatric and parapatric areas
}

Maija Laaksonen ${ }^{1 *}$, Tero Klemola', Eeva Feuth², Jani J. Sormunen', Anna Puisto ${ }^{1}$, Satu Mäkelä', Ritva Penttinen³, Kai Ruohomäki ${ }^{1}$, Jari Hänninen ${ }^{3}$, Ilari E. Sääksjärvi ${ }^{3}, \|$ ppo Vuorinen ${ }^{3}$, Hein Sprong ${ }^{4}$, Jukka Hytönen ${ }^{2 \dagger}$ and Eero J. Vesterinen ${ }^{3,5+}$

\begin{abstract}
Background: Almost 3500 tick samples, originally collected via a nationwide citizen science campaign in 2015, were screened to reveal the prevalence and distribution of a wide spectrum of established and putative tick-borne pathogens vectored by Ixodes ricinus and I. persulcatus in Finland. The unique geographical distribution of these two tick species in Finland allowed us to compare pathogen occurrence between an I. ricinus-dominated area (southern Finland), an I. persulcatus-dominated area (northern Finland), and a sympatric area (central Finland).

Results: Of the analysed ticks, almost 30\% carried at least one pathogen and 2\% carried more than one pathogen. A higher overall prevalence of tick-borne pathogens was observed in I. ricinus than in I. persulcatus: 30.0\% (604/ 2014) versus $24.0 \%$ (348/1451), respectively. In addition, I. ricinus were more frequently co-infected than I. persulcatus: 2.4\% (49/2014) versus 0.8\% (12/1451), respectively. Causative agents of Lyme borreliosis, i.e. bacterial genospecies in Borrelia burgdorferi (sensu lato) group, were the most prevalent pathogens (overall 17\%). "Candidatus Rickettsia tarasevichiae" was found for the first time in I. ricinus ticks and in Finnish ticks in general. Moreover, Babesia divergens, B. venatorum and "Candidatus Neoehrlichia mikurensis" were reported for the first time from the Finnish mainland.

Conclusions: The present study provides valuable information on the prevalence and geographical distribution of various tick-borne pathogens in I. ricinus and I. persulcatus ticks in Finland. Moreover, this comprehensive subset of ticks revealed the presence of rare and potentially dangerous pathogens. The highest prevalence of infected ticks was in the I. ricinus-dominated area in southern Finland, while the prevalence was essentially equal in sympatric and $I$. persulcatus-dominated areas. However, the highest infection rates for both species were in areas of their dominance, either in south or north Finland.
\end{abstract}

Keywords: Ixodes ricinus, Ixodes persulcatus, Borrelia burgdorferi, Rickettsia, "Candidatus Neoehrlichia mikurensis", Babesia, Anaplasma, Distribution, Sympatric, Parapatric

\footnotetext{
* Correspondence: makalaa@utu.fi

† Jukka Hytönen and Eero J Vesterinen contributed equally to this work.

${ }^{1}$ Department of Biology, University of Turku, Turku, Finland

Full list of author information is available at the end of the article
}

(c) The Author(s). 2018 Open Access This article is distributed under the terms of the Creative Commons Attribution 4.0 International License (http://creativecommons.org/licenses/by/4.0/), which permits unrestricted use, distribution, and reproduction in any medium, provided you give appropriate credit to the original author(s) and the source, provide a link to the Creative Commons license, and indicate if changes were made. The Creative Commons Public Domain Dedication waiver (http://creativecommons.org/publicdomain/zero/1.0/) applies to the data made available in this article, unless otherwise stated. 


\section{Background}

Ticks are recognized as the primary vectors for several pathogenic viruses, bacteria and protozoa worldwide [1, 2]. In northern Europe, most notable tick-borne pathogens are Borrelia burgdorferi (sensu lato) spirochetes, of which at least seven genospecies are responsible for causing Lyme borreliosis (LB) [3, 4]. In Finland, the primary vectors for tick-borne pathogens are Ixodes ricinus (Linnaeus, 1758) and Ixodes persulcatus (Schulze, 1930). The nationwide distribution of these two tick species was studied recently [5] showing I. ricinus dominance in southern Finland, a sympatric area in central Finland and I. persulcatus dominance in northern Finland. Tick distribution patterns may have an important role in the distribution and diversity of tick-borne pathogens as well.

Studies have shown that I. ricinus and I. persulcatus are potential vectors for many microorganisms in addition to B. burgdorferi (s.l.) $[6,7]$. These include TBE-virus (TBEV) causing tick-borne encephalitis (TBE), Anaplasma phagocytophilum causing human granulocytic anaplasmosis (HGA) and tick-borne fever (TBF) [8, 9], species of the bacterial genus Rickettsia causing spotted fever and typhus [10], B. miyamotoi spirochete causing hard tick-borne relapsing fever [11], "Candidatus Neoehrlichia mikurensis" causing neoehrlichiosis [12], Babesia protozoans causing babesiosis in animals and humans [13], Francisella tularensis causing tularemia [14] and Bartonella henselae causing cat scratch disease, even though transmission of $B$. henselae by ticks has not been established [15, 16]. The first nationwide investigation on the distribution of Ixodes ticks infected with B. burgdorferi (s.l.), TBEV and B. miyamotoi was recently published [5]. Moreover, the first reports of $A$. phagocytophilum and Rickettsia spp. in Finnish I. ricinus ticks were published in 2016 [17, 18]. Regarding Bartonella henselae and F. tularensis, no ticks infected by these pathogens have been found in Finland.

Despite the presence of many potential pathogens in ticks in Finland, only a few tick-borne infections other than LB and TBE have been reported in humans. A single case of fatal babesiosis was described in a man with a rudimentary spleen, detected at their autopsy in 2004 [19]. Underlying reasons for the apparent discrepancy may be, for example, low pathogenicity of the putative pathogens, unclear clinical manifestations and unestablished diagnostic criteria of human infections, lack of awareness among health-care professionals of the emerging tick-borne diseases, and unavailable laboratory tests. On the other hand, the co-occurrence of several pathogens in ticks can lead to co-infections with different tick-borne pathogens in humans and animals [20-23]. Co-infections can alter the dynamics of pathogen transmission and pathogen interactions within a host animal, and increase the severity of manifestations in humans [23-25]. For example, A. phagocytophilum infects human neutrophils, modulates the immune response of the host and thereby increases susceptibility to other pathogens, including B. burgdorferi (s.l.) [26]. Thus, co-infections of tick-borne pathogens can have a significant impact on the disease manifestations making the diagnostics of these infections more challenging.

The aim of the present study was to map the major tick-borne pathogens circulating in ticks in Finland. The distribution of $I$. ricinus and $I$. persulcatus within the country creates an exceptional opportunity to study the potential differences in the prevalence of tick-borne pathogens in a sympatric area compared to areas dominated by a single tick species.

\section{Methods}

\section{Origin of the samples}

In 2015, citizens were asked to send ticks via postal mail to the University of Turku as a part of a tick collection campaign. This collection resulted in nearly 20,000 individual ticks received from all around Finland, up to the Arctic Circle. Detailed information about the collection, acquisition of the samples and tick identification has been described in a previous study [5]. Because that study also presented the occurrence of TBEV and $B$. miyamotoi in a subset of 2000 tick samples, these pathogens were not included in the present study. The presence of B. burgdorferi (s.l.) at the genospecies level was also described in the previous study [5]. However, $B$. burgdorferi (s.l.) is included in the present study since it is now identified to the genospecies level.

A subset of 3465 ticks (2014 I. ricinus and 1451 I. persulcatus) out of a total of 20,000 ticks were screened for B. burgdorferi (s.l.), Rickettsia spp., Babesia spp., Bartonella spp., Anaplasma spp., F. tularensis and "Ca. N. mikurensis". Of the 3465 samples, 175 were nymphs, four were larvae and the remaining were adults. The samples were selected to roughly represent both tick species (I. ricinus and $I$. persulcatus), and also the major collection areas, tick life stages and sex distribution of the whole collection [5]. Samples were further divided into three different distribution regions: 1 , I. ricinus-dominated area (southern Finland); 2, sympatric area (central Finland) and 3, I. persulcatus-dominated area (northern Finland) (Fig. 1a).

DNA was extracted from the tick samples using NucleoSpin ${ }^{\bullet}$ RNA kits and RNA/DNA buffer sets (Thermo Fisher Scientific, Waltham, USA), following the kit protocols (RNA Kit: Rev. 16 May 2014 and RNA/ DNA buffer set: Rev. 08 May 2014). DNA extracts were stored at $-20{ }^{\circ} \mathrm{C}$.

\section{Tick species identification using genetic methods}

Tick species, if unknown after morphological identification $(n=146)$, was determined (decisively 95 I. ricinus and $51 \mathrm{I}$. persulcatus) in a species-specific duplex real-time quantitative PCR (qPCR) assay as previously 

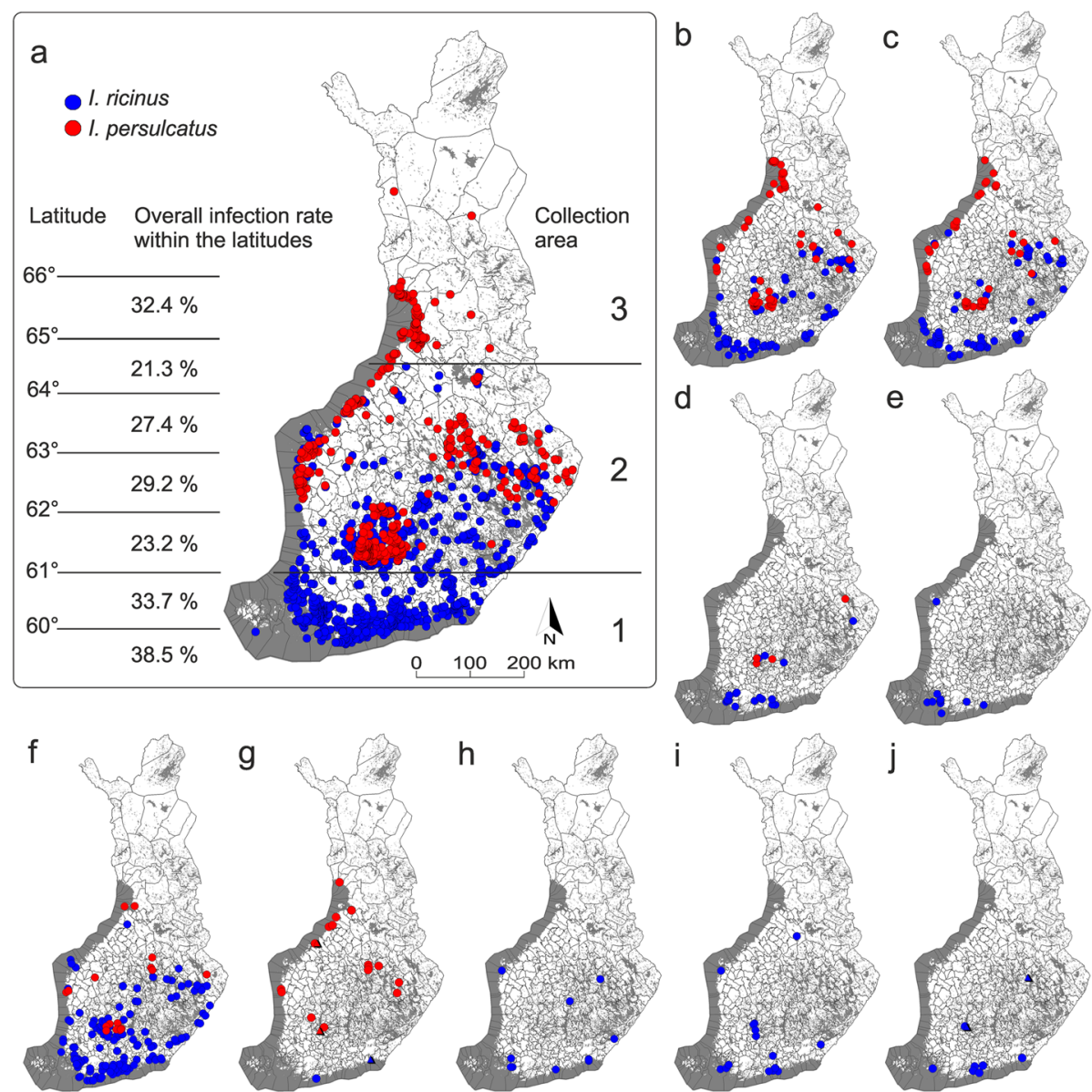

Fig. 1 Geographical distribution of the analysed samples with collection information (coordinates) provided by citizens ( $n=3418$ ). Blue dots indicate collection points of I. ricinus samples and red dots I. persulcatus. a Map showing the geographical distribution of all samples analysed: I. ricinus $(n=1997)$ and $I$. persulcatus $(n=1421)$. Overall infection rates within the latitudes are shown in the left. 1: I. ricinus-dominated area; 2 : sympatric area; and 3: I. persulcatus-dominated area are lined in the right. The following maps show the geographical distribution of the observed pathogens in the tick samples: b Borrelia garinii $(n=200)$; c B. afzelii $(n=149)$; d B. valaisiana $(n=25)$; e B. burgdorferi $(s . s).(n=13) ; \mathbf{f}$ Rickettsia helvetica $(n=231) ; \mathbf{g}$ "Candidatus Rickettsia tarasevichiae" $(n=20)$ and R. monacensis $(n=3)$ as triangles; $\mathbf{h}$ Anaplasma phagocytophilum $(n=12) ; \mathbf{i}$ "Candidatus Neoehrlichia mikurensis" ( $n=17)$; j Babesia venatorum $(n=7)$ and B. divergens $(n=2)$ as triangles

described [18]. Briefly, IXO-I2-F4 and IXO-I2-R4 primers targeting a fragment of Ixodes spp. internal transcribed spacer 2 (ITS2) gene were used to amplify genus-specific segments, and Ipe-I2-P4 and Iri-I2-P4 probes were used to match the ITS2 region for either tick species (I. persulcatus or I. ricinus, respectively; Table 1). DNA samples from I. ricinus and I. persulcatus confirmed by sequencing in an earlier study [27] were used as positive controls, and double-distilled water $\left(\mathrm{ddH}_{2} \mathrm{O}\right)$ was used instead of sample DNA as a negative control in each assay.

\section{Detection of pathogens in tick samples}

Bbsl-ospA-F and Bbsl-ospA-R primers, and a BbslospA-P probe (Table 1) amplifying a fragment of the outer surface protein $\mathrm{A}(\operatorname{ssp} A)$ gene, were used to detect B. burgdorferi (s.l.) DNA, as previously described [5].
Positive and negative controls $[B$. burgdorferi (sensu stricto) strain B31 ATCC 35210 and $\mathrm{ddH}_{2} \mathrm{O}$, respectively] were included in all runs.

For screening Rickettsia, Anaplasma, "Ca. N. mikurensis", Babesia, F. tularensis and Bartonella, aliquots of original DNA samples were first pooled (10 samples per pool, $5 \mu \mathrm{l}$ of each sample) due to low expected prevalence. For Anaplasma, Babesia and "Ca. N. mikurensis" screening, multiplex qPCR assays were first used. Briefly, qPCRs were first performed in $11 \mu$ l reaction volumes using the primers and probes displayed in Table 1. For Bartonella and Rickettsia screening, a duplex qPCR assay was first used in $8 \mu \mathrm{l}$ volume using the primers and probes displayed in Table 1. Primers and probe (Table 1) targeting the $23 \mathrm{KDa}$ gene were used to detect Francisella tularensis DNA. Individual samples from positive pools were analysed in $5 \mu \mathrm{l}$ reaction volume. 
Table 1 Primers and probes used in tick species determination and pathogen screening

\begin{tabular}{|c|c|c|c|c|}
\hline Primer/probe name & Target & Nucleotide sequence $\left(5^{\prime} \rightarrow 3^{\prime}\right)$ & Amplicon size $(b p)^{a}$ & Reference \\
\hline \multicolumn{5}{|l|}{ Real-time: PCR } \\
\hline Bbsl-ospA-F & \multirow[t]{3}{*}{ B. burgdorferi ospA } & AATATTTATTGGGAATAGGTCTAA & \multirow[t]{3}{*}{59} & \multirow[t]{3}{*}{ [83] } \\
\hline Bbsl-ospA-R & & CACCAGGCAAATCTACTGA & & \\
\hline Bbsl-ospA-P & & [6FAM]-TTAATAGCATGTAAGCAAAATGTTAGCA-[DDQ1] & & \\
\hline IXO-I2-F4 & Ixodes spp. ITS2 & TCTCGTGGCGTTGATTTGC & \multirow[t]{4}{*}{64} & \multirow[t]{4}{*}{ [27] } \\
\hline IXO-I2-R4 & Ixodes spp. ITS2 & CTGACGGAAGGCTACGACG & & \\
\hline Ipe-12-P4 & 1. persulcatus ITS2 & [FAM]-TGCGTGGAAAGAAAACGAG-[BHQ1] & & \\
\hline |ri-12-P4 & 1. ricinus ITS2 & [VIC]-TGCTCGAAGGAGAGAACGA-[BHQ1] & & \\
\hline Rspp-F & \multirow[t]{3}{*}{ Rickettsia spp. gltA } & GAGAGAAAATTATATCCAAATGTTGAT & \multirow[t]{3}{*}{100} & \multirow[t]{3}{*}{ [84] } \\
\hline Rspp-R & & AGGGTCTTCGTGCATTTCTT & & \\
\hline Rspp-P & & [Cy5]-CATTGTGCCATCCAGCCTACGGT-[BHQ3] & & \\
\hline Bab18S-F & \multirow[t]{3}{*}{ Babesia spp. 185 rRNA } & CAGCTTGACGGTAGGGTATTGG & \multirow[t]{3}{*}{20} & \multirow[t]{3}{*}{ [85] } \\
\hline Bab18S-R & & TCGAACCCTAATTCCCCGTTA & & \\
\hline Bab18S-P & & [HEX]-CGAGGCAGCAACGG-[BHQ1] & & \\
\hline ApMSP2-F & \multirow[t]{3}{*}{ Anaplasma spp. Msp2 } & ATGGAAGGTAGTGTTGGTTATGGTATT & \multirow[t]{3}{*}{30} & \multirow[t]{3}{*}{ [86] } \\
\hline ApMSP2-R & & TTGGTCTTGAAGCGCTCGTA & & \\
\hline ApMSP-P & & [CY5]-TGGTGCCAGGGTTGAGCTTGAGATTG-[BBQ650] & & \\
\hline CNeGroEL-F & \multirow{3}{*}{$\begin{array}{l}\text { "Ca. Neoehrlichia mikurensis" } \\
\text { GroEL }\end{array}$} & CCTTGAAAATATAGCAAGATCAGGTAG & \multirow[t]{3}{*}{47} & \multirow[t]{3}{*}[87]{} \\
\hline CNeGroEL-R & & CCACCACGTAACTTATTTAGCACTAAAG & & \\
\hline CNeGroEL-P & & $\begin{array}{l}\text { [FAM]-CCTCTACTAATTATTGCWGAAGATGTAGAAGG } \\
\text { TGAAGC-[BHQ1] }\end{array}$ & & \\
\hline BartssRA-F & \multirow[t]{3}{*}{ Bartonella spp. ssrA } & GCTATGGTAATAAATGGACAATGAAATAA & \multirow[t]{3}{*}{255} & \multirow[t]{3}{*}{ [88] } \\
\hline BartssRA-R & & GCTTCTGTTGCCAGGTG & & \\
\hline BartssRA-P & & [FAM]-ACCCCGCTTAAACCTGCGACG-[BHQ1] & & \\
\hline Ftu23-F & \multirow[t]{3}{*}{ F. tularensis $23 \mathrm{Kda}$} & TGAGATGATAACAAGACAACAGGTAAC & \multirow[t]{3}{*}{30} & \multirow[t]{3}{*}{ [89] } \\
\hline Ftu23-R & & GGATGAGATCCTATACATGCAGTAGGA & & \\
\hline Ftu23-P & & [FAM]-CCATTCATGTGAGAACTG-[BHQ1] & & \\
\hline \multicolumn{5}{|l|}{ PCR } \\
\hline B5Sborseq-F & \multirow[t]{2}{*}{ Borrelia IGS } & GAGTTCGCGGGAGAGTAGGTTATTGCC & \multirow[t]{2}{*}{367} & \multirow[t]{2}{*}[28]{} \\
\hline 23Sborseq- $R$ & & TCAGGGTACTTAGATGGTTCACTTCC & & \\
\hline CS877-F & \multirow[t]{2}{*}{ Rickettsia spp. gltA } & GGGGACCTGCTCACGGCGG & 381 & [90] \\
\hline CS1258-R & & ATTGCAAAAAGTACAGTGAACA & & \\
\hline Ana2-F & Anaplasma spp. 165 rRNA & CAAGCTTAACACATGCAAGTCGAAC & 894 & [91] \\
\hline Ana2-R & & CCCTTCCGTTAAGAAGGATCTAATC & & \\
\hline BabNu2-F & Babesia spp. 185 & GACACAGGGAGGTAGTGACAAG & 357 & [92] \\
\hline BabNu2-R & & CTAAGAATTTCACCTCTGACAGT & & \\
\hline
\end{tabular}

Abbreviations: ospA outer surface protein, ITS2 internal transcribed spacer, gltA bacterial citrate synthase gene, 185 and 16S ribosomal RNA genes, Msp2 surface protein antigen, GroEL chaperonin protein, ssrA transfer-messenger RNA, Kda lipoprotein, IGS intergenic spacer region

${ }^{\mathrm{a} A m p l i c o n}$ size without nucleotides of primers

Detailed protocols of all qPCR assays are presented in Additional file 1: Methods.

Samples were analysed in three replicate reactions carried out on 384-well plates. Three positive and negative control reactions were used in each assay. Samples were considered positive when successful amplification was detected in at least two replicate reactions. The thermal cycling profile used for all qPCR assays was: $95{ }^{\circ} \mathrm{C}$ for 5 min, followed by 50 cycles of $95{ }^{\circ} \mathrm{C}$ for $10 \mathrm{~s}$ and $60{ }^{\circ} \mathrm{C}$ for $30 \mathrm{~s}$. Thermal cycling was carried out at the Finnish Microarray and Sequencing Centre (FMSC, Turku, Finland) using QuantStudio ${ }^{\mathrm{Tm}} 12 \mathrm{~K}$ Flex Real-Time PCR 
System (Life Technologies Inc., Carlsbad, CA, USA). Results were analysed using QuantStudio ${ }^{\text {Tx }} 12$ K Flex Software v.1.2.2.

\section{Sequencing}

The 5S-23S rDNA (rrfA-rrlB) intergenic spacer region (IGS) was sequenced from samples found positive for $B$. burgdorferi (s.l.) to identify the bacteria to genospecies level as previously described [28].

Samples found positive for Rickettsia spp., Anaplasma spp. and Babesia spp. by qPCR were sequenced using PCR primers displayed in Table 1. Detailed protocols of all PCRs are presented in Additional file 1: Methods.

Electrophoresis was carried out to confirm amplification success by running $1 \mu \mathrm{l}$ of PCR product on $1.5 \%$ agarose gel. PCR products were purified by mixing $1 \mu \mathrm{l}$ EXO I enzyme, $1 \mu \mathrm{l}$ SAP enzyme and $8 \mu \mathrm{l}$ of PCR product, after which the samples were first incubated for 5 min at $37{ }^{\circ} \mathrm{C}$ and then heated for $10 \mathrm{~min}$ at $80{ }^{\circ} \mathrm{C}$. Purified samples were sent to Macrogen Inc. Europe (Amsterdam, Netherlands) for sequencing. The sequences were trimmed using Geneious 11.1.2 and run through BLAST (www.ncbi.nlm.nih.gov/BLAST/) and compared with reference sequences listed in the GenBank nucleotide sequence database (www.ncbi.nlm.nih.gov/genbank/).

\section{Data management and statistical analyses}

Some of the tick samples received in the collection campaign were delivered in one shipment, indicating that the samples were from one sender. Such ticks were not necessarily independent observations, as generally assumed by basic statistical tests, because they likely shared either collection location or host animal/human individual, or both. It was often the case that ticks in one letter represented only one tick species and developmental stage. Therefore, we conducted formal statistical testing only for a couple of specific cases (see below), but otherwise tabulated frequencies and percentage values in a descriptive manner only.

With statistical tests we specifically analysed whether there was a difference in total infection rate (all pathogens combined) and B. burgdorferi (s.l.) or Rickettsia spp. prevalence between adult I. persulcatus and I. ricinus. Other pathogen groups were not statistically analysed due to low infection prevalence. In the subsequent phase, we tested whether there was a difference in pathogen prevalence between I. ricinus- and I. persulcatus-dominated areas and the sympatric area. Larvae and nymphs were ignored due to their relatively low sample sizes $(n=179)$ and low numbers of positive pathogen detections. We modelled the probability of a tick sample being positive for a pathogen by running a generalized estimating equation (GEE), a specific type of generalized linear mixed model for clustered observations, with binomial error distribution and logit link function. The shipment ID was set as a clustering factor, while the species and collection area of the tick were fixed explanatory factors in consecutive tests but never entered as fixed factors to the same model. Statistical testing was run with the IBM SPSS Statistics software v.23 (Armonk, NY, USA).

\section{Results}

\section{Overall pathogen prevalence}

A total of 3465 tick samples, consisting of 2014 I. ricinus and 1451 I. persulcatus samples from the I. ricinus- and $I$. persulcatus-dominated areas and from the sympatric area, were analysed for the presence of pathogens, including the most common and some putative tick-borne pathogens circulating in ticks in Europe. Both the total infection rate and the diversity of different tick-borne pathogens was higher for I. ricinus (30.0\%, five pathogen groups) than for I. persulcatus (24.0\%, three pathogen groups) (Table 2). The GEE model conducted for the adult samples indicated significantly higher probability of finding infected I. ricinus [estimated marginal mean (with 95\% confidence interval) was $0.31(0.27-0.34)]$ than I. persulcatus [0.25 (0.22-0.29)] (Wald statistics, $\chi^{2}=4.75, d f=1, P=0.029$ ). The total prevalence of mono- and co-infected ticks reached $25.7 \%$ $(892 / 3465)$ and $1.7 \%$ (60/3465), respectively.

\section{Pathogen prevalence in parapatric and sympatric areas}

The highest prevalence of infected ticks was observed in the I. ricinus-dominated area in southern Finland (32.6\%), and the lowest prevalence in the sympatric area in central Finland (25.4\%). The GEE model also indicated a significantly higher probability of finding infected adults from the I. ricinus-dominated area compared to the sympatric area $[I$. ricinus-dominated area, 0.31 (0.27-0.35); I. persulcatus-dominated area, $0.28(0.22-$ $0.36)$; sympatric area, $0.25(0.23-0.27)]\left(\chi^{2}=7.01, d f=2\right.$, $P=0.030)$. However, the only pathogen group with significant difference in infection prevalence in adult samples between $I$. ricinus-dominated area and sympatric area was B. burgdorferi (s.l.) [I. ricinus-dominated area, $0.24(0.20-0.29) ; I$. persulcatus-dominated area, $0.18(0.13-0.24)$; sympatric area, $0.14(0.13-0.16)]\left(\chi^{2}=\right.$ 23.40, $d f=2, P<0.001)$.

When investigating the number of infected ticks on the different latitudes in steps of one degree (approximately $110 \mathrm{~km}$ ), the highest infection rates were found from the area below the latitude of $60^{\circ} \mathrm{N}(38.5 \%, n=104)$, between the latitudes of $60^{\circ} \mathrm{N}$ and $61^{\circ} \mathrm{N}(33.7 \%, n=$ 808 ) and from the area between the latitudes of $65^{\circ} \mathrm{N}$ and $66^{\circ} \mathrm{N}(32.4 \%, n=148)$ (Fig. 1a). In contrast, the lowest rate was from the area between the latitudes of $64^{\circ} \mathrm{N}$ and $65^{\circ} \mathrm{N}(21.3 \%, n=127)$. 
Table 2 Prevalence (\%) of studied pathogens in I. ricinus and I. persulcatus samples

\begin{tabular}{|c|c|c|c|c|c|c|c|c|}
\hline Species & $\begin{array}{l}\text { Collection } \\
\text { area }\end{array}$ & $\begin{array}{l}\text { No. of ticks } \\
\text { analysed }\end{array}$ & $\begin{array}{l}\text { No. of ticks } \\
\text { infected (\%) }\end{array}$ & $\begin{array}{l}\text { B. burgdorferi (s.l.) } \\
n(\%)\end{array}$ & $\begin{array}{l}\text { Rickettsia spp. } \\
n(\%)\end{array}$ & $\begin{array}{l}\text { "Ca. N. mikurensis" } \\
n(\%)\end{array}$ & $\begin{array}{l}\text { Anaplasma spp. } \\
n(\%)\end{array}$ & $\begin{array}{l}\text { Babesia spp } \\
n(\%)\end{array}$ \\
\hline \multirow[t]{4}{*}{ I. ricinus } & 1 & 994 & 325 (32.6) & $202(20.3)$ & $126(12.6)$ & $11(1.1)$ & $12(1.2)$ & $7(0.7)$ \\
\hline & 2 & 998 & $277(27.8)$ & $124(12.4)$ & $152(15.2)$ & $6(0.6)$ & $7(0.7)$ & $4(0.4)$ \\
\hline & 3 & 5 & 0 & 0 & 0 & 0 & 0 & 0 \\
\hline & a & 17 & 2 & 1 & 1 & 0 & 0 & 0 \\
\hline Subtotal & & 2014 & $604(30.0)$ & $327(16.2)$ & 279 (13.9) & $17(0.8)$ & $19(1.0)$ & $11(0.5)$ \\
\hline \multirow[t]{4}{*}{ I. persulcatus } & 1 & 0 & 0 & 0 & 0 & 0 & 0 & 0 \\
\hline & 2 & 1160 & $271(23.4)$ & $200(17.2)$ & $78(6.7)$ & 0 & $2(0.2)$ & 0 \\
\hline & 3 & 261 & 69 (26.4) & $55(21.1)$ & $16(6.1)$ & 0 & 0 & 0 \\
\hline & a & 30 & 8 & 8 & 0 & 0 & 0 & 0 \\
\hline Subtotal & & 1451 & $348(24.0)$ & $263(18.1)$ & $94(6.5)$ & 0 & $2(0.1)$ & 0 \\
\hline Total & & 3465 & $952(27.4)$ & $590(17.0)$ & 373 (10.8) & $17(0.5)$ & $21(0.6)$ & $11(0.3)$ \\
\hline
\end{tabular}

Abbreviations: 1 , I. ricinus-dominated area in south Finland; 2 , sympatric area of both species in middle Finland; 3, I. persulcatus-dominated area in north Finland (Fig. 1a)

${ }^{\text {a }}$ Tick samples that were not categorized into collection areas due to inaccurate collection information provided by citizens

\section{B. burgdorferi (s.l.) positivity}

The most prevalent pathogen group was B. burgdorferi (s.l.), which was detected in $17.0 \%$ of the screened tick samples (Table 2). The prevalence was $16.2 \%$ for I. ricinus and $18.1 \%$ for I. persulcatus. A significantly higher probability of B. burgdorferi (s.l.) infection was found in I. persulcatus adults [0.22 (0.19-0.25)] compared with $I$. ricinus adults $[0.16(0.13-0.18)]\left(\chi^{2}=8.50, d f=1, P=\right.$ $0.004)$, even in the sympatric area (I. persulcatus adults [0.17 (0.15-0.20)], I. ricinus adults [0.12 (0.10-0.15)], Wald statistics, $\chi^{2}=7.68, d f=1, P=0.006$ ).

Out of the B. burgdorferi (s.l.) positive samples $(n=$ 590), 394 were further identified to genospecies level (Table 3). Four different genospecies were identified. Sequences were at least $98 \%$ identical to the $5 \mathrm{~S}-23 \mathrm{~S}$ ribosomal RNA intergenic spacer of B. valaisiana (GenBank: KX906937 and KX906938 from Slovakia), B. afzelii (GQ387036 from Switzerland, KX906945 and KX906933 from Slovakia and KY038873 from Romania), B. garinii (KX906934, KX906935 and KX906940 from Slovakia) and B. burgdorferi (s.s.) (X57791, origin not given). Our sequences are presented in Additional file 2: Table S1. Among I. ricinus samples, B. garinii (44.6\%) and B. afzelii $(40.7 \%)$ were the predominant genospecies, followed by B. valaisiana (9.1\%) and B. burgdorferi (s.s.) (5.6\%). Among I. persulcatus samples, B. garinii was clearly the predominant genospecies (62.6\%), followed by $B$. afzelii (35.0\%) and B. valaisiana (2.5\%). B. burgdorferi (s.s.) was not detected in I. persulcatus.

The distribution maps drawn from the positive $B$. burgdorferi (s.l.) samples are shown in Fig. 1b-e. The highest prevalence of infected $I$. ricinus was observed in southern Finland (I. ricinus-dominated area), while the highest prevalence of infected $I$. persulcatus was observed in northern Finland (I. persulcatus-dominated area) (Table 2).

\section{Rickettsia spp. positivity}

The next most prevalent pathogen group was Rickettsia spp., which was detected in $10.8 \%$ of the screened tick samples (Table 2). The prevalence was $13.9 \%$ for I. ricinus and $6.5 \%$ for I. persulcatus. The GEE model also indicated a significantly higher probability of finding Rickettsia-positive I. ricinus adults [0.13 (0.10-0.17)] than I. persulcatus adults $[0.05(0.04-0.08)]\left(\chi^{2}=27.17\right.$, $d f=1, P<0.001)$. Of the 373 positive samples, 254 were successfully sequenced (Table 3). From these, 231 amplicons were at least $98 \%$ identical to the gltA of $R$.

Table 3 Prevalence (\%) of pathogen species identified by sequencing in I. ricinus and I. persulcatus samples

\begin{tabular}{|c|c|c|c|c|c|c|c|c|c|c|}
\hline \multirow[t]{2}{*}{ Species } & \multicolumn{10}{|c|}{ No. (\%) of ticks infected with certain pathogen species } \\
\hline & $\mathrm{Bg}$ & $\mathrm{Ba}$ & BV & Bss & $\mathrm{Rh}$ & CRt & $\mathrm{Rm}$ & Ap & Bad & Bav \\
\hline I. ricinus & $103 / 231(44.6)$ & $94 / 231(40.7)$ & $21 / 231(9.1)$ & $13 / 231(5.6)$ & 199/201 (99.0) & $1 / 201(0.5)$ & $1 / 201(0.5)$ & $12 / 12(100)$ & $2 / 9(22.2)$ & $7 / 9(77.8)$ \\
\hline I. persulcatus & $102 / 163(62.6)$ & $57 / 163(35.0)$ & $4 / 163(2.5)$ & 0 & $32 / 53(60.4)$ & 19/53 (35.8) & $2 / 53(3.8)$ & 0 & 0 & 0 \\
\hline Total & 205/394 (52.0) & $151 / 394(38.3)$ & 25/394 (6.4) & $13 / 394(3.3)$ & $231 / 254(90.9)$ & 20/254 (7.9) & $3 / 254(1.2)$ & $12 / 12(100)$ & $2 / 9(22.2)$ & 7/9 (77.8 \\
\hline
\end{tabular}

Abbreviations: Bg, Borrelia garinii; Ba, B. afzelii; Bv, B. valaisiana; Bss, B. burgdorferi (sensu stricto); Rh, Rickettsia helvetica; CRt, "Ca. R. tarasevichiae"; Rm, R. monacensis; Ap, Anaplasma phagocytophilum; Bad, Babesia divergens; Bav, $B$. venatorum 
helvetica (GenBank: KF447530 from France), 20 amplicons had at least $99 \%$ sequence identity with the gltA of "Ca. R. tarasevichiae" (KU361212 from Mongolia) and three amplicons were at least $98 \%$ identical to the gltA of $R$. monacensis (KY203388 from Italy). Rickettsia helvetica was clearly the most abundant species among I. ricinus samples (99\%), and only two samples were positive for R. monacensis or "Ca. R. tarasevichiae" (Table 3). Among I. persulcatus samples, $R$. helvetica was also predominant (60.4\%), followed by "Ca. R. tarasevichiae" (35.8\%) and $R$. monacensis (3.8\%). The distribution of the positive Rickettsia samples corresponded to the distribution of the whole subset of ticks (Fig. 1f, g).

\section{Anaplasma spp. positivity}

In total, Anaplasma spp. was detected in $0.6 \%$ of the screened DNA samples (Table 2) The prevalence was $1.0 \%$ for $I$. ricinus and $0.1 \%$ for $I$. persulcatus. From 19 positive $I$. ricinus samples, 12 were identified as $A$. phagocytophilum by sequencing (Table 3 ). Amplicons were at least $99 \%$ identical to the $16 S$ of $A$. phagocytophilum (GenBank: KY114936 from Croatia). Neither of the two positive I. persulcatus samples could be identified to species level due to a poor DNA sequence trace. The distribution map drawn from the positive $A$. phagocytophilum samples is shown in Fig. 1h.

\section{Other pathogens}

"Ca. N. mikurensis" was detected in $0.5 \%$ of the screened DNA samples and the prevalence was $0.8 \%$ for I. ricinus (Table 2). "Ca. N. mikurensis" DNA was not detected in $I$. persulcatus samples. The distribution of the positive "Ca. N. mikurensis" was rather aggregated as most of the positive samples were collected from urbanized areas near the cities of Helsinki, Tampere and Turku in southern Finland (Fig. 1i).

Babesia spp. was detected in $0.3 \%$ of all the screened DNA samples (Table 2), and the prevalence was $0.5 \%$ for I. ricinus. No infected $I$. persulcatus ticks were found. Nine positive samples were successfully sequenced, of which seven were identified as B. venatorum (77.8\%) and two were identified as $B$. divergens $(22.2 \%)$. Sequences were at least $99 \%$ identical to the reference sequences obtained from GenBank (B. divergens: U16370, origin not given, KY242392 from Poland; $B$. venatorum: KM289158 from Spain). The distribution of the positive Babesia samples was also rather aggregated (Fig. 1j). All positive samples from southern Finland were $B$. venatorum while $B$. divergens were found only from samples collected in central Finland.

Francisella tularensis and Bartonella spp. were not detected in either of the tick species.

\section{Co-infection of pathogens}

Among all analysed ticks, $1.7 \%$ were found to be co-infected (Table 4). Ixodes ricinus were more frequently co-infected than $I$. persulcatus: 2.4 vs $0.8 \%$, respectively. However, when investigating co-infections among infected adult ticks, no significant differences were observed between species or the three collection areas (species: $X^{2}=1.50, d f=1, P=0.221$; collection areas: $\left.\chi^{2}=3.80, d f=2, P=0.149\right)$. Co-infection prevalence for adult infected ticks was $8.1 \%$ for I. ricinus and $3.2 \%$ for $I$. persulcatus. A higher diversity of different pathogen infections was also observed in I. ricinus (6 combinations) than in $I$. persulcatus (1 combination). Most of the co-infections (68.3\%) were between B. burgdorferi (s.l.) and Rickettsia spp. pathogens.

\section{Pathogens in larvae and nymphs}

From 179 samples of juvenile life stages (nymph and larva), 33 (18.4\%) were infected with B. burgdorferi (s.l.), Rickettsia or "Ca. N. mikurensis". Borrelia burgdorferi (s.l.) and Rickettsia prevalences in juvenile life stages (13.4 and 5.6\%, respectively) were lower than in adults (17.3 and $11.1 \%$, respectively). In contrast, the prevalence of "Ca. N. mikurensis" in juvenile life stages was higher than in adults ( 2.2 vs $0.4 \%$, respectively). However, three of the four " $\mathrm{Ca}$. N. mikurensis"-positive nymphs were collected from the same location, and positive samples were therefore strongly correlated. One I. ricinus larva carried $B$. garinii, but the rest of the positive B. burgdorferi (s.l.) samples from nymphs that could be identified by sequencing were $B$. afzelii. The co-infection prevalence for juvenile ticks was $2.6 \%$ (4/ $152)$ for $I$. ricinus and $3.7 \%(1 / 27)$ for $I$. persulcatus. Three of the four positive "Ca. N. mikurensis" samples were co-infected with B. afzelii.

\section{Discussion}

The distribution of $I$. ricinus and $I$. persulcatus in Finland is fairly unique $[5,29,30]$. The southern area of the country below the latitude $61^{\circ} \mathrm{N}$ is an area dominated by $I$. ricinus, while the area above $65^{\circ} \mathrm{N}$ is dominated by $I$. persulcatus. The belt between these latitudes is an area of sympatric occurrence of both species. In this study, we mapped the prevalence and distribution of an array of established and putative tick-borne pathogens in ticks in these three areas.

Overall, almost $30 \%$ of ticks were infected with at least one pathogen and $2 \%$ with more than one pathogen. Tick-borne pathogen diversity was higher in I. ricinus than in I. persulcatus. Of seven studied pathogen groups, five were detected in I. ricinus and three in I. persulcatus. A higher diversity of tick-borne pathogens in I. ricinus has also been observed in a previous study by Movila et al. [6], in which they investigated the differences of tick-borne 
Table 4 Co-infection prevalence (\%) between studied pathogens in I. ricinus and I. persulcatus samples

\begin{tabular}{|c|c|c|c|c|c|c|c|c|c|}
\hline Species & $\begin{array}{l}\text { Collection } \\
\text { area }\end{array}$ & $\begin{array}{l}\text { No. of ticks } \\
\text { analysed }\end{array}$ & $\begin{array}{l}\text { No. (\%) of } \\
\text { ticks co- } \\
\text { infected }\end{array}$ & $\begin{array}{l}\text { B.b. (s.l.) + } \\
\text { Rickettsia spp. }\end{array}$ & $\begin{array}{l}\text { B. b. (s.l.) + } \\
\text { Anaplasma spp. }\end{array}$ & $\begin{array}{l}\text { B. b. (s.l.) + } \\
\text { Babesia } \\
\text { spp. }\end{array}$ & $\begin{array}{l}\text { B. b. }(\text { s.l. })+\text { "Ca. } \\
\text { N. mikurensis" }\end{array}$ & $\begin{array}{l}\text { Babesia spp. + } \\
\text { Rickettsia spp. }\end{array}$ & $\begin{array}{l}\text { Anaplasma spp. + } \\
\text { Rickettsia spp. }\end{array}$ \\
\hline \multirow[t]{4}{*}{ I. ricinus } & 1 & 994 & $33(3.2)$ & $17(1.6)$ & $2(0.2)$ & $3(0.3)$ & $6(0.6)$ & $1(0.1)$ & $4(0.4)$ \\
\hline & 2 & 998 & $16(1.6)$ & $13(1.3)$ & $1(0.1)$ & 0 & 0 & $2(0.2)$ & 0 \\
\hline & 3 & 5 & 0 & 0 & 0 & 0 & 0 & 0 & 0 \\
\hline & a & 17 & 0 & 0 & 0 & 0 & 0 & 0 & 0 \\
\hline Subtotal & & 2014 & $49(2.4)$ & $30(1.5)$ & $3(0.2)$ & $3(0.2)$ & $6(0.3)$ & $3(0.2)$ & $4(0.2)$ \\
\hline \multirow{4}{*}{$\begin{array}{l}\text { I. } \\
\text { persulcatus }\end{array}$} & 1 & 0 & 0 & 0 & 0 & 0 & 0 & 0 & 0 \\
\hline & 2 & 1160 & $9(0.8)$ & $9(0.8)$ & 0 & 0 & 0 & 0 & 0 \\
\hline & 3 & 261 & $2(0.8)$ & $2(0.8)$ & 0 & 0 & 0 & 0 & 0 \\
\hline & a & 30 & 0 & 0 & 0 & 0 & 0 & 0 & 0 \\
\hline Subtotal & & 1451 & $11(0.8)$ & $11(0.8)$ & 0 & 0 & 0 & 0 & 0 \\
\hline Total & & 3465 & $60(1.7)$ & $41(1.2)$ & $3(0.1)$ & $3(0.1)$ & $6(0.2)$ & $3(0.1)$ & $4(0.1)$ \\
\hline
\end{tabular}

Abbreviations: B.b. (s.l.), Borrelia burgdorferi (s.l.); 1, I. ricinus-dominated area in south Finland; 2, sympatric area of both species in middle Finland; 3, I. persulcatusdominated area in north Finland (Fig. 1a)

${ }^{a}$ Tick samples that were not categorized into collection areas due to inaccurate collection information provided by citizens

microorganism communities in I. ricinus and I. persulcatus in distinct geographical regions of eastern Europe and European Russia. However, in our study, I. ricinus were also more frequently mono- and co-infected than I. persulcatus, which is contrary to the observations made by Movila et al. [6]. Infection rates can be influenced by many factors, e.g. life stage, sex, collection site of the ticks and by the season of tick collection. In Finland and neighboring countries, I. persulcatus adults have only one activity peak in April or May and are found to be questing only until July, while I. ricinus usually has two activity peaks during summer with the latter occurring during late $\mathrm{Au}$ gust or September $[5,31,32]$. In our dataset, $85 \%$ of the $I$. persulcatus samples were collected by the end of May, while $85 \%$ of the I. ricinus samples were not collected until the end of July. Of all the analysed ticks, $95 \%$ were adults and less than one third were males, with these ratios equal in both species. Some of the studied pathogens in our study were analysed with single primers and some were multiplexed. Moreover, some were analysed individually while some were first pooled. These different methods could potentially cause a small bias on the prevalence of the studied pathogens. Nevertheless, our pathogen prevalence results mostly correspond with the prevalence results observed in the neighboring countries, suggesting that sample pooling and PCR multiplexing did not cause any major differences in the observed prevalences. However, slightly fewer positive findings could have been due to our "majority rules" approach when analyzing PCR results. Samples were considered positive when successful amplification was detected in at least two replicate reactions. A positive sample in one out of three replicates could suggest a low level of DNA close to the detection level rather than contamination of a sample. However, there were only a few samples that had only one positive replicate.

Not surprisingly, the most prevalent tick-borne pathogen was B. burgdorferi (s.l.) (17\%), the causative agent of $\mathrm{LB}$, which is the most prevalent tick-borne disease in Finland (around 6000-7000 cases yearly; 120 cases per 100,000 inhabitants) [33]. The observed prevalence in our study is in accordance with the average prevalence rates found in Europe (17.8\% for adult I. ricinus ticks) [34]. Even in the sympatric area, prevalence was significantly higher in I. persulcatus than I. ricinus (17.2 and $12.4 \%$, respectively). A higher prevalence of $B$. burgdorferi (s.l.) in I. persulcatus than in I. ricinus ticks has also been observed in previous studies conducted in sympatric regions [30, 35, 36].

The most common B. burgdorferi (s.l.) genospecies detected in our study were B. garinii and B. afzelii. In comparison to reported $B$. garinii prevalence in I. ricinus ticks in Europe, a higher prevalence was observed in the present study [34]. Interestingly, a particularly high $B$. garinii prevalence (62.6\% from Borrelia-positive ticks) was observed in I. persulcatus ticks. Migratory songbirds such as Turdus species are known as common B. garinii reservoir hosts while rodents are known as the main $B$. afzelii reservoir hosts [37, 38]. There can be differences in the occurrence of these reservoir species between countries, as well as fluctuations in their abundance (especially in voles) between different years [39], which might affect the proportions of Borrelia genospecies. Moreover, the activity peak of $I$. persulcatus in Finland co-occurs with the spring migration of Turdus spp. birds which might affect the higher B. garinii prevalence observed in I. persulcatus. Borrelia afzelii was observed relatively more often in $I$. ricinus than in $I$. persulcatus 
samples. The same observation was made in the study by Movila et al. [6]. While the evidence for human pathogenicity of B. valaisiana is poor, B. afzelii, B. garinii and $B$. burgdorferi (s.s.) are the genospecies that commonly infect people $[4,40]$. These genospecies are also often associated with different clinical manifestations. In Europe, $B$. garinii is the main cause of Lyme neuroborreliosis, while $B$. afzelii is mostly associated with skin manifestations [41, 42]. Among the identified genospecies, $B$. valaisiana was detected in $6.4 \%$ of ticks, which is in accordance with the findings in the neighboring countries (6\% in Norway, Sweden and Estonia) [30, 43, 44]. Even though, B. valaisiana is not often detected in I. persulcatus, it has been shown that in the sympatric areas of I. ricinus and $I$. persulcatus, B. valaisiana may exchange vectors and can also be found in I. persulcatus [30, 45]. In our study, $B$. valaisiana prevalence among $B$. burgdorferi (s.l.)-positive $I$. persulcatus samples $(2.5 \%)$ was similar to the prevalence observed in Estonia, where these two tick species live in sympatric areas as well [30]. B. burgdorferi (s.s.) was not detected in I. persulcatus in this study, even though it has previously been found in I. persulcatus in a coastal Finnish region of the Gulf of Bothnia around the city of Kokkola [46].

Our study also revealed the occurrence of some less-known pathogens present in ticks in Finland. In contrast to B. burgdorferi (s.l.), all such pathogens had a higher prevalence in I. ricinus than in I. persulcatus samples. The most prevalent pathogen after B. burgdorferi (s.l.) spirochetes was Rickettsia spp. (10.8\%). The observed prevalence is slightly higher than the reported prevalence in the neighboring country, Estonia (5.1\%) [47]. Rickettsial DNA was more frequently detected in $I$. ricinus (13.9\%) than in I. persulcatus (6.5\%). The majority of the positive samples were identified as $R$. helvetica (90.9\%). Ixodes ricinus is regarded as the main vector of $R$. helvetica, while the role of I. persulcatus is less studied. Rickettsia helvetica has been detected in I. persulcatus ticks before but with lower prevalence than in $I$. ricinus [6]. In our study, the prevalence of $R$. helvetica in I. ricinus (9.9\%) was over four times higher than in $I$. persulcatus (2.2\%), even though $R$. helvetica did not have a significant difference in infection prevalence between the collection areas. In contrast, "Ca. R. tarasevichae" was detected almost exclusively in I. persulcatus (18/19 positive samples). This is the first report of " $\mathrm{Ca}$. R. tarasevichae" in Finland, and also the most western report. Moreover, to our knowledge this is the first report of the pathogen in I. ricinus. Interestingly, the positive I. ricinus sample is from southern Finland, the area of parapatric occurrence of $I$. ricinus. "Ca. R. tarasevichae" has previously been reported from neighboring countries Russia and Estonia [47, 48], where I. persulcatus is a common tick species. A minority (1.2\%) of the Rickettsia-positive samples were identified as $R$. monacensis. This pathogen was first detected in I. ricinus ticks in 2013-2014 in southwestern Finland with similar prevalence to this study [18]. Patient cases from Spain and China suggest that "Ca. R. tarasevichae" and $R$. monacensis are both capable of human infection $[49,50]$.

Anaplasma spp. was the most abundant pathogen of the family Anaplasmataceae and almost all of the positive samples were detected in I. ricinus. The prevalence for I. ricinus was $1.0 \%$, which is lower than the prevalence detected previously in questing $I$. ricinus adults in southwestern Finland (9.2\%) [17]. However, reports from all over Europe have observed pronounced differences in prevalence among countries, study localities and tick life stages, ranging from 0 to $67 \%[9,51,52]$. Anaplasma phagocytophilum is frequently detected in I. ricinus in Europe and it was the only Anaplasma species we detected. The prevalence for I. persulcatus was only $0.1 \%$ and neither of the two positive samples could be identified to species level by sequencing. Anaplasma phagocytophilum is the agent of human granulocytic anaplasmosis (HGA), and confirmed cases of HGA have been reported since 1997 in Europe [51, 53-55]. Another human pathogenic member of the family Anaplasmataceae, "Ca. N. mikurensis" was detected for the first time in ticks from mainland Finland, and only in I. ricinus (overall prevalence of $0.5 \%$ ). The observed prevalence was lower than in previous observations made in Europe $[56,57]$. The presence of " $\mathrm{Ca}$. N. mikurensis" in I. ricinus ticks was previously analysed in ticks collected in 2013-2014 in southwestern Finland, but no positivity was detected [18]. However, our recent, still unpublished tick sampling data (Sormunen et al., in press), reveal the occurrence of this pathogen in southwestern Finland since 2015, agreeing with observations of the current study. "Ca. N. mikurensis" was also detected in I. ricinus ticks, collected in the years 2006-2013 in Estonia, with prevalence rates ranging from 1 to $9.1 \%$ [58].

Previous studies about Babesia spp. prevalence in Finnish ticks are scarce. The prevalence observed for Babesia spp. in I. ricinus samples in the current study $(0.5 \%)$ corresponds to results reported from neighboring countries [30, 59-61]. Babesia venatorum was the most prevalent species in our study. In Europe and China this pathogen has been involved in the several documented cases of human babesiosis [62, 63]. Babesia microti was not detected, even though it is known to commonly infect rodents in Finland and was previously found in $I$. persulcatus tick in the Kokkola coastal region [46, 64]. The absence of $B$. microti in our study is likely due to low prevalence in Finnish ticks. B. divergens was detected in two samples. However, $B$. divergens is genetically very similar to $B$. capreoli. Since sequences should be identical to GenBank reference sequence U16370 to 
be regarded as $B$. divergens [65] and one of our positive samples were only $99 \%$ identical to this reference, we cannot be entirely sure whether this is truly $B$. divergens or B. capreoli. In Finland, a single case of fatal babesiosis in 2004 was caused by $B$. divergens and believed to be transmitted by a tick bite [19].

Neither Bartonella spp. nor Francisella tularensis were found in the ticks, although some Bartonella species have recently been reported from mammals and arthropods in Finland $[66,67]$. The relevance of ticks as vectors for human bartonellosis is not yet verified. Bartonella have been reported in one I. persulcatus tick in Estonia (with a total prevalence of $0.2 \%$ ) [6], while the prevalence in questing I. ricinus ticks in Europe has varied up to $48.2 \%$ in nymphs and $12 \%$ in adult ticks [68]. Although hard ticks are important vectors of $F$. tularensis in North America and central Europe [69-71], their role in the transmission of $F$. tularensis in northern Europe is poorly understood. In Fennoscandia, the primary route of human $F$. tularensis infection is probably through mosquito bites [69, 72-74].

In our study, about $7 \%$ of infected ticks were found to be co-infected. Most of the co-infections were between B. burgdorferi (s.l.) and Rickettsia spp., as expected due to their high prevalence. Interestingly, a particularly high number of co-infections were observed in positive " $\mathrm{Ca}$. N. mikurensis" samples, of which over half (6/11) were co-infected with B. burgdorferi (s.l.) (Table 4). All of these co-infected B. burgdorferi (s.l.) samples were identified as $B$. afzelii and half of them were in nymph samples. "Ca. N. mikurensis" and B. afzelii share the same natural hosts (voles and mice) and co-infection with these pathogens has recently been shown to occur in nymphs more often than expected under random co-occurrence $[57,75,76]$, as a result of larvae receiving both pathogens by feeding on co-infected hosts. The amount of different co-infection combinations was higher in I. ricinus (six) than in I. persulcatus (only one), partly due to the lower pathogen diversity and infection rates in I. persulcatus in our study. The co-infection rate in I. ricinus was $2.4 \%$, which roughly corresponds with the results by Movila et al. (3.4\%) [6]. However, in the same study, the co-infection rate in I. persulcatus samples was much higher than in ours (4.3 vs $0.8 \%)$. This is likely due to lower prevalence of Rickettsia infected $I$. persulcatus in our study. We examined co-infections only at genus level, and did not consider double infections among different pathogen species, e.g. B. afzelii and B. garinii. On average, $68 \%$ of the microbial sequences could be identified to species level. The rest of the sequence results were of poor quality (blurry or poorly resolved signal peaks in the chromatogram), which could have resulted from impurities in the DNA samples.
Species of B. burgdorferi (s.l.) and Rickettsia were detected beyond the latitude of $65^{\circ} \mathrm{N}$, while the members of family Anaplasmataceae and Babesia spp. were detected only south of $65^{\circ} \mathrm{N}$, perhaps due to lower abundance of $I$. ricinus in higher latitudes. The prevalence of infected ticks did not correlate directly with latitude, since the highest prevalence of infected ticks were found from the area below $61^{\circ} \mathrm{N}$ and from the area between $65^{\circ} \mathrm{N}$ and $66^{\circ} \mathrm{N}$. Other ecological factors of the area, such as rainfall, distance to coast or inland waters, vegetation and variety of host animals, may have a bigger influence on pathogen diversity or proportion of the infected ticks [77]. According to previous observations, pathogen prevalence is also expected to correlate with the density of questing ticks at the collection sites [78-80]. Since our tick samples were gathered by citizens from all over Finland in a positive correlation to human population density, we cannot straightforwardly consider tick densities in our analyses. Interestingly, the highest infection rates were observed in areas of parapatric occurrence of one species, I. ricinus in southern and I. persulcatus in northern Finland. The assumption that in the zone of sympatry, the pathogen prevalence in one vector species would either increase or decrease by the influence of other closely related species, was not supported. Pathogen prevalence was lower for both species in the zone of their sympatry, indicating that other environmental factors might explain the lower prevalence in that area. When comparing infection rates between the collection areas by combining all the analysed ticks (excluding the information of tick species), the highest infection rate was observed in southern Finland, but infection rates did not differ between central and northern Finland (I. ricinus-dominated area: $32.6 \%$; sympatric area: 25.4\%; and $I$. persulcatus-dominated area: $25.9 \%)$. It remains unclear whether the higher prevalence in southern Finland is related to I. ricinus dominance or other environmental factors. Rickettsia spp. was the only pathogen group with a descending trend in infection prevalence towards the higher latitudes (I. ricinus-dominated area: $12.6 \%$; sympatric area: $10.7 \%$; and $I$. persulcatus-dominated area: 6.0\%). However, the differences between the collection areas were not significant.

\section{Conclusions}

The unique distribution of I. ricinus and I. persulcatus in Finland allowed us to compare the pathogen distributions in parapatric and sympatric areas of tick occurrence. The highest infection rate was observed in southern Finland, but infection rates did not differ between sympatric and $I$. persulcatus-dominated areas. However, the highest infection rates for both species were observed in areas of their dominance, either in southern or northern Finland. Furthermore, our comprehensive subset of Finnish ticks revealed the presence of rare and potentially pathogenic 
bacteria, such as "Ca. N. mikurensis" and "Ca. R. tarasevichae", for the first time in mainland Finland. Although only a few human infections caused by organisms other than B. burgdorferi (s.l.) and TBEV have been reported in Finland so far, and it is known that infections due to these emerging pathogens can be either asymptomatic or mild $[81,82]$, the risk of these tick-borne pathogens for public health should not be neglected.

\section{Additional files}

Additional file 1: Methods. Detailed protocols of GPCR assays and sequencing. (DOCX $25 \mathrm{~kb}$ )

Additional file 2: Table S1. Tick-borne pathogens in Finland: Comparison of Ixodes ricinus and I. persulcatus in sympatric and parapatric areas. (XLSX $13 \mathrm{~kb})$

\section{Acknowledgements \\ We thank Tuula Rantasalo (Institute of Biomedicine, University of Turku) for helping with the pathogen screenings, and Manoj Fonville (RIVM) with excellent technical support in the determination of Borrelia genospecies. We thank the company Biotop for professional help with lab consumables. We thank the Finnish Functional Genomics Centre (FFGC, Turku, Finland) for the laboratory services. We also thank the two anonymous for their constructive comments.}

\section{Funding}

This work was supported by the Jane and Aatos Erkko Foundation; Sakari Alhopuro; Jenny and Antti Wihuri Foundation; Pfizer Inc. (Finland); Maj and Tor Nessling Foundation; The Varsinais-Suomi Regional Fund of the Finnish Cultural Foundation; and the Academy of Finland (grants 292701).

\section{Availability of data and materials}

The data supporting the conclusions of this article are included within the article and its additional files. The datasets used and analysed during the present study are available from the corresponding author upon reasonable request.

\section{Authors' contributions}

RP, ML, TK, JJS, EJV, IV, JHä, IES and KR planned and conducted the collection campaign of the ticks and ML, TK, JHy and EJV designed the current study on tick-borne pathogens. ML performed morphological identification of tick samples and conducted the main laboratory analyses, interpreted the data and drafted the manuscript. TK planned statistical tests and provided major comments on the manuscript. EF, JJS and SM performed DNA extractions and pathogen screenings. AP performed morphological identification of tick samples and pathogen screenings. RP lead the collection campaign and performed morphological identification of tick samples. KR determined coordinates of the samples. JHä, JHy, ML, IES and IV acquired funding. HS analysed Borrelia genospecies and provided IGS PCR method. EJV and JHy provided major comments on the manuscript. All authors read and approved the final manuscript.

\section{Ethics approval and consent to participate}

Not applicable.

\section{Consent for publication}

Not applicable.

\section{Competing interests}

The authors declare that they have no competing interests.

\section{Publisher's Note}

Springer Nature remains neutral with regard to jurisdictional claims in published maps and institutional affiliations.

\section{Author details}

${ }^{1}$ Department of Biology, University of Turku, Turku, Finland. ${ }^{2}$ Institute of Biomedicine, University of Turku, Turku, Finland. ${ }^{3}$ Biodiversity Unit, University of Turku, Turku, Finland. ${ }^{4}$ Centre for Infectious Disease Control, National Institute for Public Health and Environment (RIVM), Bilthoven, Netherlands.

${ }^{5}$ Department of Agricultural Sciences, University of Helsinki, Helsinki, Finland.

Received: 18 June 2018 Accepted: 2 October 2018

Published online: 24 October 2018

\section{References}

1. Kernif T, Leulmi H, Raoult D, Parola P. Emerging tick-borne bacterial pathogens. Microbiol Spectr. 2016. https://doi.org/10.1128/microbiolspec. El10-0012-2016

2. Dantas-Torres F, Chomel BB, Otranto D. Ticks and tick-borne diseases: a One Health perspective. Trends Parasitol. 2012;28:437-46.

3. Stanek G, Wormser GP, Gray J, Strle F. Lyme borreliosis. Lancet. 2012;379:461-73.

4. Rudenko N, Golovchenko M, Grubhoffer L, Oliver JH. Updates on Borrelia burgdorferi sensu lato complex with respect to public health. Ticks Tick Borne Dis. 2011:2:123-8.

5. Laaksonen M, Sajanti E, Sormunen JJ, Penttinen R, Hanninen J, Ruohomaki $\mathrm{K}$, et al. Crowdsourcing-based nationwide tick collection reveals the distribution of Ixodes ricinus and $I$. persulcatus and associated pathogens in Finland. Emerg Microbes Infect. 2017;6:e31.

6. Movila A, Dubinina HV, Sitnicova N, Bespyatova L, Uspenskaia I, Efremova G, et al. Comparison of tick-borne microorganism communities in Ixodes spp. of the Ixodes ricinus species complex at distinct geographical regions. Exp Appl Acarol. 2014;63:65-76.

7. Michelet L, Delannoy S, Devillers E, Umhang G, Aspan A, Juremalm M, et al. High-throughput screening of tick-borne pathogens in Europe. Front Cell Infect Microbiol. 2014;4:103.

8. Rar V, Golovljova I. Anaplasma, Ehrlichia, and "Candidatus Neoehrlichia" bacteria: pathogenicity, biodiversity, and molecular genetic characteristics, a review. Inf Genet Evol. 2011;11:1842-61.

9. Stuen S, Granquist EG, Silaghi C. Anaplasma phagocytophilum - a widespread multi-host pathogen with highly adaptive strategies. Front Cell Infect Microbiol. 2013:3:31.

10. Parola P, Paddock CD, Socolovschi C, Labruna MB, Mediannikov O, Kernif T, et al. Update on tick-borne rickettsioses around the world: a geographic approach. Clin Microbiol Rev. 2013;26:657-702.

11. Platonov AE, Karan LS, Kolyasnikova NM, Makhneva NA, Toporkova MG, Maleev W, et al. Humans infected with relapsing fever spirochete Borrelia miyamotoi, Russia. Emerg Inf Dis. 2011;17:1816-23.

12. Grankvist A, Andersson PO, Mattsson M, Sender M, Vaht $K$, Hoper L, et al. Infections with the tick-borne bacterium "Candidatus Neoehrlichia mikurensis" mimic noninfectious conditions in patients with B cell malignancies or autoimmune diseases. Clin Infect Dis. 2014;58:1716-22.

13. Homer MJ, Aguilar-Delfin I, Telford SR 3rd, Krause PJ, Persing DH. Babesiosis. Clin Microbiol Rev. 2000;13:451-69.

14. Petersen JM, Mead PS, Schriefer ME. Francisella tularensis: an arthropodborne pathogen. Vet Res. 2009;40:1

15. Billeter S, Levy M, Chomel B, Breitschwerdt E. Vector transmission of Bartonella species with emphasis on the potential for tick transmission. Med Vet Entomol. 2008;22:1-15

16. Telford SR 3rd, Wormser GP. Bartonella spp. transmission by ticks not established. Emerg Infect Dis. 2010;16:379-84.

17. Sormunen JJ, Penttinen R, Klemola T, Vesterinen EJ, Hänninen J. Anaplasma phagocytophilum in questing Ixodes ricinus ticks in southwestern Finland. Exp Appl Acarol. 2016:70:491-500.

18. Sormunen JJ, Penttinen R, Klemola T, Hänninen J, Vuorinen I, Laaksonen M, et al. Tick-borne bacterial pathogens in southwestern Finland. Parasit Vectors. 2016;9:168.

19. Haapasalo K, Suomalainen P, Sukura A, Siikamaki H, Jokiranta TS. Fatal babesiosis in man, Finland, 2004. Emerg Infect Dis. 2010;16:1116-8.

20. Swanson SJ, Neitzel D, Reed KD, Belongia EA. Coinfections acquired from Ixodes ticks. Clin Microbiol Rev. 2006:19:708-27.

21. Belongia EA. Epidemiology and impact of coinfections acquired from Ixodes ticks. Vector-Borne Zoonotic Dis. 2002;2:265-73.

22. Moutailler S, Moro CV, Vaumourin E, Michelet L, Tran FH, Devillers E, et al. Co-infection of ticks: the rule rather than the exception. PLoS Negl Trop Dis. 2016;10:e0004539 
23. Diuk-Wasser MA, Vannier E, Krause PJ. Coinfection by lxodes tick-borne pathogens: ecological, epidemiological, and clinical consequences. Trends Parasitol. 2016;32:30-42.

24. Thomas V, Anguita J, Barthold SW, Fikrig E. Coinfection with Borrelia burgdorferi and the agent of human granulocytic ehrlichiosis alters murine immune responses, pathogen burden, and severity of Lyme arthritis. Infect Immun. 2001;69:3359-71.

25. Holden K, Hodzic E, Feng S, Freet KJ, Lefebvre RB, Barthold SW. Coinfection with Anaplasma phagocytophilum alters Borrelia burgdorferi population distribution in C3H/HeN mice. Infect Immun. 2005;73:3440-4.

26. Rikihisa Y. Mechanisms of obligatory intracellular infection with Anaplasma phagocytophilum. Clin Microbiol Rev. 2011;24:469-89.

27. Sormunen JJ, Klemola T, Vesterinen EJ, Vuorinen I, Hytönen J, Hänninen J, et al. Assessing the abundance, seasonal questing activity, and Borrelia and tick-borne encephalitis virus (TBEV) prevalence of Ixodes ricinus ticks in a Lyme borreliosis endemic area in southwest Finland. Ticks Tick-Borne Dis. 2016;7:208-15

28. Coipan EC, Fonville M, Tijsse-Klasen E, van der Giessen, Joke WB, Takken W, et al. Geodemographic analysis of Borrelia burgdorferi sensu lato using the 5S-23S rDNA spacer region. Inf Genet Evol. 2013;17:216-22.

29. Bugmyrin SV, Bespyatova LA, Korotkov YS, Burenkova LA, Belova OA Romanova LI, et al. Distribution of Ixodes ricinus and I. persulcatus ticks in southern Karelia (Russia). Ticks Tick-Borne Dis. 2013;4:57-62.

30. Geller J, Nazarova L, Katargina O, Golovljova I. Borrelia burgdorferi sensu lato prevalence in tick populations in Estonia. Parasit Vectors. 2013;6:202.

31. Bormane A, Lucenko I, Duks A, Mavtchoutko V, Ranka R, Salmina K, et al. Vectors of tick-borne diseases and epidemiological situation in Latvia in 1993-2002. Int J Med Microbiol. 2004;293(Suppl.):36-47.

32. Tokarevich N, Tronin A, Blinova O, Buzinov R, Boltenkov V, Yurasova E, Nurse J. The impact of climate change on the expansion of Ixodes persulcatus habitat and the incidence of tickborne encephalitis in the north of European Russia. Global Health Action. 2011:4:8448.

33. Sajanti E, Virtanen M, Helve O, Kuusi M, Lyytikainen O, Hytonen J, et al. Lyme borreliosis in Finland, 1995-2014. Emerg Infect Dis. 2017;23:1282-8.

34. Strnad M, Honig V, Ruzek D, Grubhoffer L, Rego ROM. Europe-wide metaanalysis of Borrelia burgdorferi sensu lato prevalence in questing Ixodes ricinus ticks. Appl Environ Microbiol. 2017;83:AEM-00609.

35. Kovalevskii YV, Korenberg El. Differences in Borrelia infections in adult Ixodes persulcatus and Ixodes ricinus ticks (Acari: Ixodidae) in populations of northwestern Russia. Exp Appl Acarol. 1995;19:19-29.

36. Alekseev AN, Dubinina HV, Antykova LP, Dzhivanyan TI, Rijpkema SG, Kruif $\mathrm{NV}$, et al. Tick-borne borrelioses pathogen identification in Ixodes ticks (Acarina, Ixodidae) collected in St. Petersburg and Kaliningrad Baltic regions of Russia. J Med Entomol. 1998;35:136-42.

37. Taragel'ova V, Koci J, Hanincova K, Kurtenbach K, Derdakova M, Ogden NH et al. Blackbirds and song thrushes constitute a key reservoir of Borrelia garinii, the causative agent of borreliosis in central Europe. Appl Environ Microbiol. 2008;74:1289-93.

38. Hanincova K, Schäfer S, Etti S, Sewell H, Taragelova V, Ziak D, et al. Association of Borrelia afzelii with rodents in Europe. Parasitology. 2003;126:11-20.

39. Hansson L, Henttonen $\mathrm{H}$. Gradients in density variations of small rodents: the importance of latitude and snow cover. Oecologia. 1985;67:394-402.

40. Margos G, Sing A, Fingerle V. Published data do not support the notion that Borrelia valaisiana is human pathogenic. Infection. 2017:45:567-9.

41. Strle F, Ružić-Sabljić E, Cimperman J, Lotrič-Furlan S, Maraspin V. Comparison of findings for patients with Borrelia garinii and Borrelia afzelii isolated from cerebrospinal fluid. Clin Inf Dis. 2006;43:704-10.

42. Jahfari S, Krawczyk A, Coipan EC, Fonville M, Hovius JW, Sprong H, et al. Enzootic origins for clinical manifestations of Lyme borreliosis. Inf Genet Evol. 2017:49:48-54.

43. Jenkins A, Hvidsten D, Matussek A, Lindgren P, Stuen S, Kristiansen B. Borrelia burgdorferi sensu lato in Ixodes ricinus ticks from Norway: evaluation of a PCR test targeting the chromosomal flaB gene. Exp Appl Acarol. 2012 58:431-9.

44. Fraenkel CJ, Garpmo U, Berglund J. Determination of novel Borrelia genospecies in Swedish Ixodes ricinus ticks. J Clin Microbiol. 2002;40:3308-12.

45. Alekseev AN, Dubinina HV, Van De Pol I, Schouls LM. Identification of Ehrlichia spp. and Borrelia burgdorferi in lxodes ticks in the Baltic regions of Russia. J Clin Microbiol. 2001;39:2237-42.

46. Alekseev $\mathrm{AN}$, Dubinina $\mathrm{HV}$, Jääskeläinen $\mathrm{AE}$, Vapalahti $\mathrm{O}$, Vaheri A. First report on tick-borne pathogens and exoskeletal anomalies in Ixodes persulcatus schulze (Acari: Ixodidae) collected in Kokkola coastal region, Finland. Int J Acarol. 2007;33:253-8.

47. Katargina O, Geller J, Ivanova A, Värv K, Tefanova V, Vene S, et al. Detection and identification of Rickettsia species in Ixodes tick populations from Estonia. Ticks Tick-Borne Dis. 2015;6:689-94.

48. Shpynov S, Fournier P, Rudakov N, Raoult D. 'Candidatus Rickettsia tarasevichiae' in Ixodes persulcatus ticks collected in Russia. Ann N Y Acad Sci. 2003;990:162-72.

49. Jia N, Zheng Y, Jiang J, Ma L, Cao W. Human infection with Candidatus Rickettsia tarasevichiae. N Engl J Med. 2013;369:1178-80.

50. Jado I, Oteo JA, Aldamiz M, Gil H, Escudero R, Ibarra V, et al. Rickettsia monacensis and human disease, Spain. Emerg Infect Dis. 2007;13:1405-7.

51. Blanco J, Oteo J. Human granulocytic ehrlichiosis in Europe. Clin Microbio Inf. 2002;8:763-72.

52. Strle F. Human granulocytic ehrlichiosis in Europe. Int J Med Microb. 2004 293(Suppl.):27-35.

53. Brouqui $P$, Dumler J, Lienhard R, Brossard M, Raoult D. Human granulocytic ehrlichiosis in Europe. Lancet. 1995;346:782-3.

54. Edouard S, Koebel C, Goehringer F, Socolovschi C, Jaulhac B, Raoult D, et al. Emergence of human granulocytic anaplasmosis in France. Ticks Tick-Borne Dis. 2012;3:403-5.

55. Petrovec M, Lotric Furlan S, Zupanc TA, Strle F, Brouqui P, Roux V, et al. Human disease in Europe caused by a granulocytic Ehrlichia species. J Clin Microbiol. 1997;35:1556-9.

56. Derdáková M, Václav $R$, Pangrácova-Blaňárová L, Selyemová D, Koči J, Walder G, et al. Candidatus Neoehrlichia mikurensis and its co-circulation with Anaplasma phagocytophilum in Ixodes ricinus ticks across ecologically different habitats of central Europe. Parasit Vectors. 2014;7:160.

57. Kjelland V, Paulsen KM, Rollum R, Jenkins A, Stuen S, Soleng A, et al. Tickborne encephalitis virus, Borrelia burgdorferi sensu lato, Borrelia miyamotoi, Anaplasma phagocytophilum and Candidatus Neoehrlichia mikurensis in Ixodes ricinus ticks collected from recreational islands in southern Norway. Ticks Tick-Borne Dis. 2018;9:1098-102.

58. Ivanova A, Geller J, Katargina O, Värv K, Lundkvist Å, Golovljova I. Detection of Candidatus Neoehrlichia mikurensis and Ehrlichia muris in Estonian ticks. Ticks Tick-Borne Dis. 2017:8:13-7.

59. Katargina O, Geller J, Vasilenko V, Kuznetsova T, Järvekülg L, Vene S, et al. Detection and characterization of Babesia species in Ixodes ticks in Estonia. Vector-Borne Zoon Dis. 2011;11:923-8.

60. Karlsson ME, Andersson MO. Babesia species in questing Ixodes ricinus, Sweden. Ticks Tick-Borne Dis. 2016;7:10-2

61. Rar V, Epikhina T, Livanova N, Panov V. Genetic diversity of Babesia in Ixodes persulcatus and small mammals from North Ural and West Siberia, Russia. Parasitology. 2011;138:175-82.

62. Jiang J, Zheng Y, Jiang R, Li H, Huo Q, Jiang B, et al. Epidemiological, clinical, and laboratory characteristics of 48 cases of "Babesia venatorum" infection in China: a descriptive study. Lancet Inf Dis. 2015;15:196-203.

63. Hunfeld K, Hildebrandt A, Gray J. Babesiosis: recent insights into an ancient disease. Int J Parasitol. 2008:38:1219-37.

64. Kallio ER, Begon M, Birtles RJ, Bown KJ, Koskela E, Mappes T, et al. First report of Anaplasma phagocytophilum and Babesia microti in rodents in Finland. Vector-Borne Zoon Dis. 2014;14:389-93.

65. Malandrin L, Jouglin M, Sun Y, Brisseau N, Chauvin A. Redescription of Babesia capreoli (Enigk and Friedhoff, 1962) from roe deer (Capreolus capreolus): isolation, cultivation, host specificity, molecular characterisation and differentiation from Babesia divergens. Int J Parasitol. 2010;40:277-84.

66. Veikkolainen V, Vesterinen EJ, Lilley TM, Pulliainen AT. Bats as reservoir hosts of human bacterial pathogen, Bartonella mayotimonensis. Emerg Infect Dis. 2014;20:960-7.

67. Lilley TM, Veikkolainen V, Pulliainen AT. Molecular detection of Candidatus Bartonella hemsundetiensis in bats. Vector-Borne Zoon Dis. 2015;15:706-8.

68. Dietrich F, Schmidgen T, Maggi RG, Richter D, Matuschka FR, Vonthein R, et al. Prevalence of Bartonella henselae and Borrelia burgdorferi sensu lato DNA in Ixodes ricinus ticks in Europe. Appl Environ Microbiol. 2010;76:1395-8.

69. Ryden P, Bjork R, Schafer ML, Lundstrom JO, Petersen B, Lindblom A, et al. Outbreaks of tularemia in a boreal forest region depends on mosquito prevalence. J Infect Dis. 2012;205:297-304

70. Keim $\mathrm{P}$, Johansson A, Wagner DM. Molecular epidemiology, evolution, and ecology of Francisella. Ann N Y Acad Sci. 2007;1105:30-66.

71. Eisen RJ, Mead PS, Meyer AM, Pfaff LE, Bradley KK, Eisen L. Ecoepidemiology of tularemia in the southcentral United States. Am J Trop Med Hyg. 2008;78:586-94. 
72. Eliasson H, Lindbäck J, Nuorti P, Arneborn M, Giesecke J, Tegnell A. The 2000 tularemia outbreak: a case-control study of risk factors in diseaseendemic and emergent areas, Sweden. Emerg Inf Dis. 2002;8:956-60.

73. Rossow H, Ollgren J, Klemets P, Pietarinen I, Saikku J, Pekkanen E, et al. Risk factors for pneumonic and ulceroglandular tularaemia in Finland: a population-based case-control study. Epidemiol Infect. 2014;142:2207-16.

74. Thelaus J, Andersson A, Broman T, Bäckman S, Granberg M, Karlsson L, et al. Francisella tularensis subspecies holarctica occurs in Swedish mosquitoes, persists through the developmental stages of laboratory-infected mosquitoes and is transmissible during blood feeding. Microb Ecol. 2014;67:96-107.

75. Andersson M, Bartkova S, Lindestad O, Råberg L. Co-infection with 'Candidatus Neoehrlichia mikurensis' and Borrelia afzelii in Ixodes ricinus ticks in southern Sweden. Vector-Borne Zoon Dis. 2013;13:438-42.

76. Richter D, Matuschka FR. "Candidatus Neoehrlichia mikurensis", Anaplasma phagocytophilum, and Lyme disease spirochetes in questing european vector ticks and in feeding ticks removed from people. J Clin Microbiol. 2012;50:943-7.

77. Coipan EC, Jahfari S, Fonville M, Maassen CB, van der Giessen J, Takken W, et al. Spatiotemporal dynamics of emerging pathogens in questing lxodes ricinus. Front Cell Infect Microbiol. 2013;3:36.

78. Randolph SE. The shifting landscape of tick-borne zoonoses: tick-borne encephalitis and Lyme borreliosis in Europe. Philos Trans R Soc Lond B Biol Sci. 2001:356:1045-56.

79. Ogden N. Changing geographic ranges of ticks and tick-borne pathogens: drivers, mechanisms and consequences for pathogen diversity. Front Cell Inf Microbiol. 2013;3:46.

80. Ogden N, Casey A, French N, Adams J, Woldehiwet Z. Field evidence for density-dependent facilitation amongst lxodes ricinus ticks feeding on sheep. Parasitology. 2002;124:117-25.

81. Ismail N, Bloch KC, McBride JW. Human ehrlichiosis and anaplasmosis. Clin Lab Med. 2010;30:261-92.

82. Tijsse-Klasen E, Jacobs JJ, Swart A, Fonville M, Reimerink JH, Brandenburg $\mathrm{AH}$, et al. Small risk of developing symptomatic tick-borne diseases following a tick bite in The Netherlands. Parasit Vectors. 2011;4:17.

83. Ivacic L, Reed KD, Mitchell PD, Ghebranious N. A LightCycler TaqMan assay for detection of Borrelia burgdorferi sensu lato in clinical samples. Diagn Microbiol Infect Dis. 2007;57:137-43.

84. Labruna MB, Whitworth T, Horta MC, Bouyer DH, McBride JW, Pinter A, et al. Rickettsia species infecting Amblyomma cooperi ticks from an area in the state of Sao Paulo, Brazil, where Brazilian spotted fever is endemic. J Clin Microbiol. 2004;42:90-8.

85. Øines $\varnothing$, Radzijevskaja J, Paulauskas A, Rosef O. Prevalence and diversity of Babesia spp. in questing Ixodes ricinus ticks from Norway. Parasit Vectors. 2012;5:156.

86. Courtney JW, Kostelnik LM, Zeidner NS, Massung RF. Multiplex real-time PCR for detection of Anaplasma phagocytophilum and Borrelia burgdorferi. I Clin Microbiol. 2004:42:3164-8.

87. Jahfari S, Fonville M, Hengeveld P, Reusken C, Scholte E, Takken W, et al. Prevalence of Neoehrlichia mikurensis in ticks and rodents from North-west Europe. Parasit Vectors. 2012;5:74.

88. Diaz MH, Bai Y, Malania L, Winchell JM, Kosoy MY. Development of a novel genus-specific real-time PCR assay for detection and differentiation of Bartonella species and genotypes. J Clin Microbiol. 2012;50:1645-9.

89. Skottman T, Piiparinen H, Hyytiäinen H, Myllys V, Skurnik M, Nikkari S. Simultaneous real-time PCR detection of Bacillus anthracis, Francisella tularensis and Yersinia pestis. Eur J Clin Microbiol Inf Dis. 2007;26:207-11.

90. Mediannikov O, Sidelnikov Y, Ivanov L, Mokretsova E, Fournier P, Tarasevich I, et al. New acute tick-borne rickettsiosis caused by Rickettsia heilongjiangensis in the Russian Far East. Clin Microbiol Inf. 2004;10(Suppl.):78.

91. Hildebrandt A, Krämer A, Sachse S, Straube E. Detection of Rickettsia spp. and Anaplasma phagocytophilum in Ixodes ricinus ticks in a region of Middle Germany (Thuringia). Ticks Tick-Borne Dis. 2010;1:52-6.

92. Georges K, Loria G, Rili S, Greco A, Caracappa S, Jongejan F, et al. Detection of haemoparasites in cattle by reverse line blot hybridisation with a note on the distribution of ticks in Sicily. Vet Parasitol. 2001;99:273-86.

\section{Ready to submit your research? Choose BMC and benefit from:}

- fast, convenient online submission

- thorough peer review by experienced researchers in your field

- rapid publication on acceptance

- support for research data, including large and complex data types

- gold Open Access which fosters wider collaboration and increased citations

- maximum visibility for your research: over $100 \mathrm{M}$ website views per year

At BMC, research is always in progress.

Learn more biomedcentral.com/submissions 